Revista de BIOLOGía TROPICAL

\title{
Biochemical changes in Araucaria angustifolia (Araucariaceae) zygotic embryos during the storage
}

\author{
Cristhyane Garcia ${ }^{1}$, Cileide Maria Medeiros Coelho ${ }^{2 *}$, Marcelo Maraschin ${ }^{1}$, Francine Lunardi \\ Farias Soares $^{1}$, Miguel Pedro Guerra ${ }^{1} \&$ Danilo Wilhelm-Filho ${ }^{3}$ \\ 1. Departmento de Fitotecnia, Universidade Federal de Santa Catarina, 88040-900, Florianópolis-SC, Brazil; \\ crisggargioni@hotmail.com,m2@cca.ufsc.br, lunardi.fran@gmail.com,mpguerra@cca.ufsc.br \\ 2. Departmento de Agronomia, Universidade do Estado de Santa Catarina, 88520-000, Lages-SC, Brazil; \\ cileidecoelho@yahoo.com.br \\ 3. Departamento de Zoologia e Ecologia, Universidade Federal de Santa Catarina, 88040-900, Florianópolis-SC, Brazil; \\ dawifi@ccb.ufsc.br \\ * Correspondence
}

Received 13-X-2014. Corrected 20-V-2015. Accepted 22-VI-2015.

\begin{abstract}
Reactive oxygen species (ROS) are present in all aerobic organisms, but the seed deterioration processes can increase its production. Oxidative stress caused by higher endogenous ROS may cause irreparable damage to cells, leading to the loss of seed viability. Considering that the enzyme superoxide dismutase (SOD) composes the first enzymatic antioxidant defense mechanism, this study aimed to evaluate zygotic embryos of Araucaria angustifolia recalcitrant seeds during storage regarding changes in SOD activity. Besides, some of the major alterations resulting from oxidative stress, e.g., lipid peroxidation and changes in proteins and DNA integrity were also measured. Approximately, 7000 seeds were harvested from a population in Southern Brazil and stored for 180 days under laboratory (L, laboratory temperature), refrigeration $\left(\mathrm{R}, 5 \pm 1^{\circ} \mathrm{C}\right)$ and freezing $(\mathrm{F}$, $-18 \pm 1{ }^{\circ} \mathrm{C}$ ) conditions. The analysis of lipid peroxidation through TBARS levels, SOD activity, protein profile by electrophoretic separation, and integrity of genomic DNA were performed at 0,60,120, and 180 days of storage. The results revealed an increase in lipid peroxidation and SOD activity, especially during the L storage, a condition in which there was an extensive degradation of proteins. Some proteins (i.e., 45, 32, and 31 $\mathrm{kDa}$ ) were expressed only in embryos stored under R and F conditions. No damage was observed in the nuclear DNA integrity for the evaluated period of seed storage at $\mathrm{R}$ and $\mathrm{F}$ conditions. The F samples maintained the biochemical traits of interest throughout the storage period, with the exception of the protein profile. However, such changes are limiting for the maintenance of seed viability. In conclusion, R storage can be indicated to delay the metabolic feature alterations that occur when seeds are exposed to conditions of natural ambient after harvest, extending the conservation period of A. angustifolia seeds. Rev. Biol. Trop. 63 (4): 1185-1196. Epub 2015 December 01.
\end{abstract}

Key words: Brazilian pine, recalcitrant seeds, seed deterioration, oxidative stress, superoxide dismutase.

Araucaria angustifolia (Bert.) O. Ktze is a native conifer species from the Atlantic Rain Forest (Veloso, Rangel Filho, \& Lima, 1991) in South Brazil. In its area of natural occurrence this species is one of the most important trees in ecological, economic, and social aspects (Auler, Reis, Guerra, \& Nodari, 2002; Vibrans et al., 2011; Rosenfield \& Souza, 2013). Among the trees of tropical origin, many species produce recalcitrant seeds, such as some of the Araucariaceae family (Song, Berjak, Pammenter, Ntuli, \& Fu, 2003), including A. angustifolia (Balbuena et al., 2011; FariasSoares, Burrieza, Steiner, \& Guerra, 2013), which rapidly germinate after dispersion (Löwe \& Dillenburg, 2011).

Seeds reach their maximum physiological quality after the completion of reserve 
substances allocation at physiological maturity time. From this point, the deterioration process begins, when several metabolic changes are apparent. But in recalcitrant seeds there is a pattern of indeterminate development, because they are dispersed before the full acquisition of desiccation tolerance (Barbedo \& Marcos Filho, 1998; Pammenter \& Berjak, 2000). Due to the absence of a physiological resting period at the end of development, the speed and intensity of damage are accelerated during storage of recalcitrant seeds such as for $A$. angustifolia. This is because the germination of these seeds tends to begin in a few days after shedding (Ferrandis, Bonilla, \& Osorio, 2013) and if they fail to germinate, seed viability may be lost.

Accumulation of reactive oxygen species (ROS), changes in antioxidant enzyme activity, lipid peroxidation, and changes in the biosynthesis of proteins and damage to DNA integrity are considered the most relevant metabolic events related to seed deterioration (McDonald, 1999; Santos, Menezes, \& Villela, 2004; Corte, Borges, Leite, Pereira, \& Gonçalves, 2010; Corbineau, 2012). As results of those biochemical alterations, cellular damage, senescence, and cell death are expected to occur (Halliwell \& Gutteridge, 1999), leading to reduced vigor of seeds and seedlings with morphological abnormalities.

Under stable metabolic conditions, the regulations of ROS still remain in equilibrium, which can be disturbed by (a) biotic stress (Gill \& Tuteja, 2010; Rendón, Gratão, Salva, Azevedo, \& Bragagnolo, 2013). Oxidative stress resulting from ROS induces a programmed cell death pathway (Li \& Pritchard, 2009) leading to loss of seed viability as the deteriorating process proceeds during seed storage. Antioxidant enzymes may act directly in the elimination of ROS or repair damage to the organism (Barreiros, David, \& David, 2006). The enzymatic protective mechanism, such as composed by superoxide dismutase (SOD), acts seeking to neutralize them, catalyzing the dismutation of $\mathrm{O}_{2}{ }^{\bullet-}$ generating $\mathrm{H}_{2} \mathrm{O}_{2}$ and $\mathrm{O}_{2}$ (Barbedo \& Marcos Filho, 1998; Blokhina, Virolainen, \&
Fagerstedt, 2003; Nakada et al., 2010). SOD can be found in the cell cytoplasm and in the mitochondrial matrix, being the first line of cell defense against ROS in many organisms (Alscher, Erturk, \& Health, 2002; Corte et al., 2010). However, under high stress conditions, the antioxidant defense system can be overwhelmed, losing its ability of fully protection (Alscher et al., 2002).

The peroxidation of stored lipids and components of membranes occurs when ROS levels reach a certain threshold, directly affecting normal cell function, besides aggravating oxidative stress through the production of radicals derived from lipids (Gill \& Tuteja, 2010). Thus, lipid peroxidation has been considered one of the most damaging process to living organisms, and one of the major changes involved in seeds deterioration, promoting the formation of toxic by-products, the loss of selective permeability, and the degradation of DNA and proteins (Wilson \& McDonald, 1986; Vidas et al., 1992; McDonald, 1999; Villela \& Peres, 2004; Corbineau, 2012). Therefore, it can be correlated with the decline of vigor and viability, as observed in stored rubber seeds (Paula, Borges, Borges, \& Paula, 1997).

Some studies have investigated the reduction of physiological quality of $A$. angustifolia seeds during storage, and there is a general agreement that it has a short conservation period under natural conditions, showing at most $40 \%$ germination at 120 days (Fowler, Bianchetti, \& Zanon, 1998; Amarante, Mota, Megguer, \& Ide, 2007; Garcia, Coelho, Maraschin, \& Oliveira, 2014). Furthermore, it has been reported that the freezing of seeds with high water content causes cell death. However, little has been described so far on metabolic changes after maturity and seed dispersal, including the damage from freezing to the metabolism of $A$. angustifolia seeds.

The understanding of the mechanisms of viability loss promotes the development of appropriate methods for quality maintenance, allowing the preservation of seeds under specific conditions (Li \& Pritchard, 2009). A. angustifolia is a critically endangered species 
(Thomas, 2013) and there is a general interest of conserving this genetic resource. The aim of the present work was to determine the possible changes in the metabolic features (lipid peroxidation, activity of the SOD, the protein profile, and DNA integrity) of zygotic embryos of $A$. angustifolia, upon seed storage under different temperature conditions (laboratory, refrigeration and freezing) over a period of 180 days.

\section{MATERIALS AND METHODS}

Collection and storage of seeds: Mature cones (megastrobili) of $A$. angustifolia were collected from a natural population located in the highland region of Santa Catarina state Painel county, $\left(27^{\circ} 55^{\prime} \mathrm{S}-50^{\circ} 06^{\prime} \mathrm{W}\right.$, altitude $1144 \mathrm{~m})$, Southern Brazil. The cones were collected from 25 mother trees randomly selected, and located at approximately $50 \mathrm{~m}$ away from each other. A total of 80 cones and approximately 7000 seeds were collected in May2010 , at the beginning of natural shedding. The seed sample was homogenized without previous selection and the average water content of freshly harvested seeds was $45 \%$. From the homogenized sample, respective fractions for each temperature storage condition were divided as follows: laboratory condition (without thermal control, L), refrigeration $\left(5 \pm 1{ }^{\circ} \mathrm{C}\right.$ and $45 \pm 5 \%$ of relative humidity, R), and freezing $\left(-18 \pm 1{ }^{\circ} \mathrm{C}\right.$ and $90 \pm 5 \%$ of relative humidity, F). The samples were included in sealed transparent plastic packages $(0.015 \mu \mathrm{m}$ porosity) and stored for a total period of 180 days, from July to December 2010). Seeds stored under $\mathrm{F}$ conditions were directly frozen without prior treatment in order to stop metabolism. Variations in temperature and relative humidity throughout the samples storage period under L conditions are shown in table 1 , according to the meteorological data service from Epagri/ Ciram (2011).

The assessments performed on zygotic embryos included: profile of soluble proteins, activity of superoxide dismutase, levels of lipid peroxidation, and DNA integrity. Data was obtained from the analysis of three replicates of ten embryos at $0,60,120$, and 180 days of storage in L (no thermal control), $\mathrm{R}$ and $\mathrm{F}$ conditions. Although the start of the germination process (radicle protrusion) was visually observed in some stored seeds, only embryos from non-germinating seeds were used for the analyses.

Extraction of proteins and enzymes: The proteins in the samples were extracted according to Steiner (2005), with some modifications. Samples (100 mg, dry weight) were added of $1 \mathrm{~mL}$ of extraction buffer $(20 \mathrm{mM}$ dibasic sodium phosphate, $\mathrm{pH}$ 7.5), $1 \mathrm{mM}$ EDTA, $50 \mathrm{mM}$ $\mathrm{NaCl}, 10 \%$ glycerol (v/v), $1 \mathrm{mM}$ PMSF, and $1.5 \% \beta$-mercaptoethanol (v/v). After centrifugation at $10000 \mathrm{~g}$ at $4{ }^{\circ} \mathrm{C}$ for 25 minutes, the supernatant was collected and used for all analyses except for those related to genomic DNA.

Lipid peroxidation: The accumulation of lipid oxidation products such as

TABLE 1

Temperature data for the city of Lages (Santa Catarina state, southern Brazil) during the storage of $A$. angustifolia seeds (2010)

\begin{tabular}{|c|c|c|c|c|c|c|}
\hline \multirow[b]{2}{*}{ Month } & \multicolumn{3}{|c|}{ Temperature $\left({ }^{\circ} \mathrm{C}\right)$} & \multicolumn{3}{|c|}{ Relative humidity (\%) } \\
\hline & $\begin{array}{c}\text { Monthly } \\
\text { mean }\end{array}$ & $\begin{array}{l}\text { Monthly } \\
\text { maximum }\end{array}$ & $\begin{array}{l}\text { Monthly } \\
\text { minimum }\end{array}$ & $\begin{array}{c}\text { Monthly } \\
\text { mean }\end{array}$ & $\begin{array}{l}\text { Monthly } \\
\text { maximum }\end{array}$ & $\begin{array}{l}\text { Monthly } \\
\text { minimum }\end{array}$ \\
\hline July & 11.4 & 24.6 & -3.0 & 86 & 98 & 41 \\
\hline August & 11.7 & 28.8 & 0.3 & 81 & 98 & 39 \\
\hline September & 14.4 & 26.4 & 4.9 & 80 & 98 & 36 \\
\hline October & 15.0 & 27.6 & 4.8 & 78 & 99 & 40 \\
\hline November & 17.6 & 30.0 & 4.1 & 75 & 96 & 33 \\
\hline December & 19.5 & 30.4 & 7.5 & 79 & 96 & 40 \\
\hline
\end{tabular}


malondialdehyde (MDA) is normally used to measure the lipid peroxidation in stored seeds (Bewley \& Black, 1994; Smith \& Berjak, 1995). Following this, the lipid peroxidation was assessed spectrophotometrically (GBC UV/VIS 916 dual beam spectrophotometer) by determining the levels of thiobarbituric acid reacting substances (TBARS), which react with MDA molecules forming a pink pigment that could be read at an absorbance of $535 \mathrm{~nm}$ (Ohkawa, Ohishi, \& Yagi, 1979), in a GBC UV/VIS 916 dual beam spectrophotometer.

Activity of superoxide dismutase enzyme (SOD): The analysis of SOD (EC 1.15.1.1) activity was performed by the oxidation of adrenaline-based methodology forming the adenochrome (Misra \& Fridovich, 1972), a reaction that is delayed by the presence of SOD in the sample. The adrenaline oxidation was monitored by measuring the absorbance of the reaction medium when observed at a wavelength of $480 \mathrm{~nm}$ in a GBC UV/VIS 916 dual beam spectrophotometer. Results were expressed as SOD units (U/mg protein) after plotting 3-5 measurements of 50\% inhibition produced by the addition of the homogenate into the cuvette.

\section{Electrophoretic separation of proteins:}

For electrophoretic analysis, total proteins were precipitated with the addition of $200 \mu \mathrm{L}$ of absolute ethanol, kept overnight in refrigerator. After centrifugation at $10000 \mathrm{~g}$ at $4{ }^{\circ} \mathrm{C}$ for 35 minutes, the supernatant was discarded and total proteins resolubilized in $250 \mu \mathrm{L}$ of 20 $\mathrm{mM}$ solution of dibasic sodium phosphate $(\mathrm{pH}$ 7.5). Total protein levels served as a reference for the remaining analyses, and were quantified spectrophotometrically by the method of Bradford (1976) using bovine serum albumin as standard (BSA 0-800 $\mu \mathrm{g} / \mathrm{mL}, \mathrm{R}^{2}=0.9845$, y $=2078.7 \mathrm{x}-29.82$ ).

Aliquots $(20 \mu \mathrm{g})$ of proteins were applied in a polyacrylamide SDS-PAGE gel at $12 \%$ (separating gel) and $5 \%$ (concentrating gel) (Laemmli, 1970) at a constant voltage of $100 \mathrm{~V}$ for $120 \mathrm{~min}$, with three replications. The gels were stained with Coomassie Brilliant Blue 0.1 \% (Alfenas, 1998).

Integrity of genomic DNA: The extraction of genomic DNA from embryos of $A$. angustifolia was performed based on Doyle and Doyle $(1987 ; 1990)$ protocols. Samples (50 mg, dry weight) were added of $700 \mu \mathrm{L}$ of extraction buffer containing $1.4 \mathrm{M} \mathrm{NaCl}, 100$ $\mathrm{mM}$ Tris- $\mathrm{HCl}(\mathrm{pH} 8.0), 20 \mathrm{mM}$ EDTA $(\mathrm{pH}$ 8.0), $1 \%$ PVP $40,2 \%$ CTAB, and $0.2 \%$ of $\beta$-mercaptoethanol. The DNA samples were quantified by NanoDrop spectrophotometer (Nanodrop ${ }^{\circledR} 1000$, Thermo Scientific) at 260 $\mathrm{nm}$, in order to determine the amount to be applied in the gel, and subjected to electrophoresis on $0.8 \%$ agarose gel $(100 \mathrm{~V})$, stained with the GelRed fluorescent dye $(5 \mu \mathrm{L}$ GelRed for $50 \mathrm{~mL}$ agarose solution) and visualized under UV transilluminator (MultiDoc-It ${ }^{\mathrm{TM}}$ Digital Imaging System, UVP).

The whole experiment was conducted in split plot design, with three storage conditions (L, R, and F) as previously mentioned, and four storage periods $(0,60,120$, and 180 days). The data set of the oxidative stress analysis was subjected to the analysis of variance followed by the Tukey test $(\mathrm{p}<0.05)$ as appropriate, besides regression analysis, using the SAS statistical program (2009). The analysis of the protein and DNA electrophoresis was qualitative, in order to visually assess the presence and intensity of the bands, and the integrity and quality of the bands, respectively.

\section{RESULTS}

Lipid peroxidation: In $A$. angustifolia freshly harvested seed embryos, a lipid peroxidation of $2.29 \mu \mathrm{mol} / \mathrm{g}$ protein was observed (Fig. 1). This value remained constant only for the samples stored under $\mathrm{F}\left(-18 \pm 1{ }^{\circ} \mathrm{C}\right)$ for 180 days. For the $\mathrm{R}$ and $\mathrm{L}$ samples, an increase in lipid peroxidation of approximately three and seven times, respectively, was detected in embryos over the experimental period.

SOD activity: Embryos of freshly harvested seeds showed a SOD activity of 11.24 


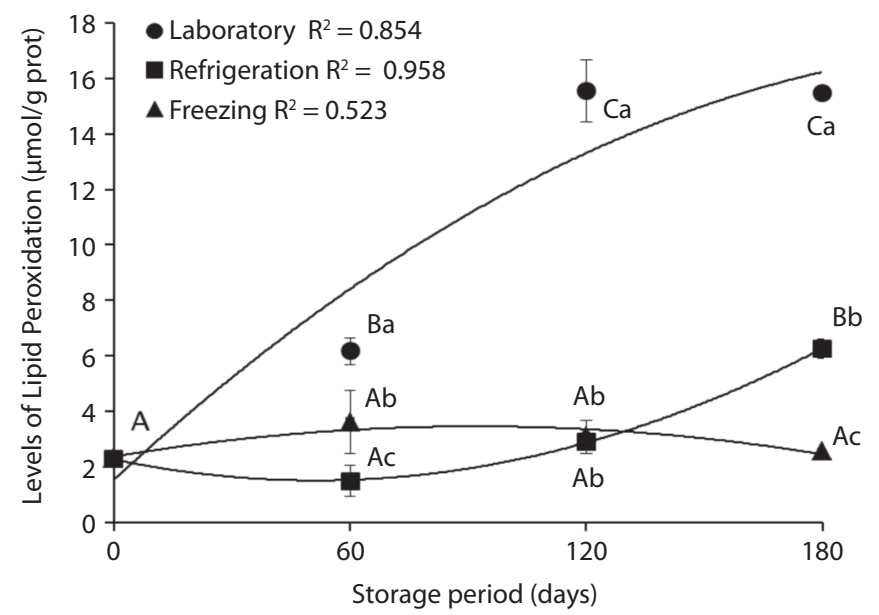

Fig. 1. Levels of lipid peroxidation ( $\mu \mathrm{mol} / \mathrm{g}$ protein) (TBARS) in Araucaria angustifolia embryos during the period of seed storage at laboratory $\left(-3\right.$ to $\left.30^{\circ} \mathrm{C}\right)$, refrigeration $\left(5 \pm 1^{\circ} \mathrm{C}\right)$, and freezing $\left(-18 \pm 1{ }^{\circ} \mathrm{C}\right)$. Laboratory $=-0.0003 \mathrm{x}^{2}+0.1311 \mathrm{x}+1.5445$; Refrigeration $=0.0003 x^{2}-0.0295 x+2.2779$; Freezing $=-0.0001 x^{2}+0.0237 x+2.3816$. Values represent the mean $(N=10)$ of four replicates for each treatment, and vertical bars are the pooled standard errors of the mean from ANOVA. Uppercase letters compare the storage periods and lowercase letters compare the storage conditions (Tukey's test, $\mathrm{P}<0.05$ ).

$\mathrm{U} / \mathrm{mg}$ protein, but some changes were observed throughout the experimental period depending on the storage conditions (Fig. 2). In samples kept at $\mathrm{L}$ condition, a 14-fold increase of SOD activity until 120 days of storage was observed, comparatively to the freshly harvested ones; followed by a sharp SOD activity decrease thereafter (Fig. 2). As for the R samples, there was a gradual increase in SOD activity, being approximately three times higher at 180 days, when compared to embryos of freshly harvested seeds. The SOD activity remained

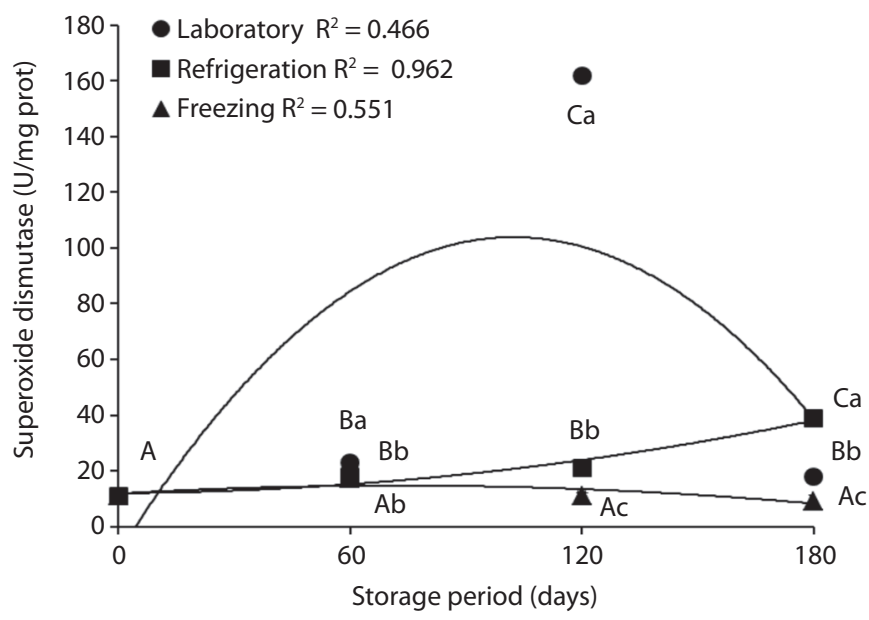

Fig. 2. Superoxide dismutase activity of (U/mg protein) Araucaria angustifolia embryos during the period of seed storage at laboratory $\left(-3\right.$ to $\left.30^{\circ} \mathrm{C}\right)$, refrigeration $\left(5 \pm 1{ }^{\circ} \mathrm{C}\right)$, and freezing $\left(-18 \pm 1{ }^{\circ} \mathrm{C}\right)$. Laboratory $=-0.0108 \mathrm{x}^{2}+2.2167 \mathrm{x}-9.5$; Refrigerator $=0.0008 \mathrm{x}^{2}+0.0075 \mathrm{x}+11.95$; Freezer $=-0.0006 \mathrm{x}^{2}+0.08 \mathrm{x}+11.8$. Values represent the mean $(\mathrm{N}=10)$ of four replicates for each treatments, and vertical bars are the pooled standard errors of the mean from ANOVA. Uppercase letters compare the storage periods and lowercase letters compare the storage conditions (Tukey's test, $\mathrm{P}<0.05$ ). 
significantly low in seed embryos stored under $\mathrm{F}$ throughout the sample period $(9.07 \mathrm{U} / \mathrm{mg}$ protein at 180 days).

Proteins electrophoretic profile: The gel of freshly harvested samples showed intense bands at approximately $55 \mathrm{kDa}, 38 \mathrm{kDa}, 20$ $\mathrm{kDa}$, and $15 \mathrm{kDa}$ (Fig. 3). Along the studied period, changes in the protein profile of $A$. angustifolia embryos associated with the storage conditions were detected. In samples of seeds stored for 60 days under $\mathrm{R}$, bands of approximately $45 \mathrm{kDa}$ and $32 \mathrm{kDa}$ (not present in freshly harvested samples) were found; besides, an increase in the intensity of the 31 $\mathrm{kDa}$ band, and the absence of the $38 \mathrm{kDa}$ band were also found. A similar condition was also observed under F storage for the 60, 120, and 180 storage periods. After 60 days of storage under L conditions, it was possible to detected a decrease in the intensity of all bands of the electrophoretic profile, and the remaining proteins (up to 180 days of storage) were those of approximately $37 \mathrm{kDa}$ and $34 \mathrm{kDa}$ (with great band intensity).

In samples stored in L conditions, protein degradation was evident and revealed by a decrease in the band intensity, mostly resulting from variations in temperature during the storage (temperature ranging between -3 and 30 ${ }^{\circ} \mathrm{C}$ - Table 1). This was not the case for samples under $\mathrm{R}\left(5 \pm 1{ }^{\circ} \mathrm{C}\right)$ and $\mathrm{F}\left(-18 \pm 1{ }^{\circ} \mathrm{C}\right)$ conditions, kept under constant and monitored temperatures throughout the storage period.

Up to 60 days of storage, the protein profile remained similar to the control regardless of the treatment, with the emergence of some bands under $\mathrm{R}$ and $\mathrm{F}$ conditions. On the other hand, electrophoretic profiles of samples stored under $\mathrm{L}$ conditions for periods longer than 60 days, presented a reduction in the band intensity associated with the protein degradation.

DNA integrity: The analysis of the DNA quality and integrity showed the absence of DNA degradation in the zygotic embryos over time and in response to different storage conditions (Fig. 4).

\section{DISCUSSION}

The results showed that the level of lipid peroxidation in seeds stored in a freezer $(-18$ $\pm 1{ }^{\circ} \mathrm{C}$ ) remained constant during the experimental period, probably due to the death of the seeds, which suppresses any metabolic activity,

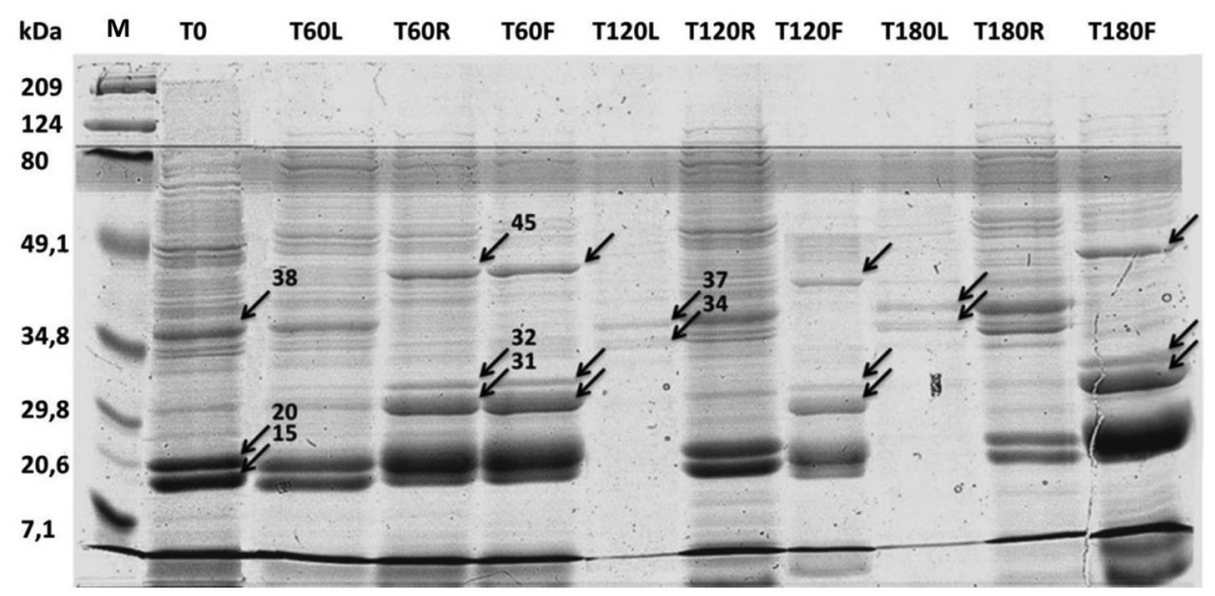

Fig. 3. Electrophoretic profiles of reserve proteins in Araucaria angustifolia embryos during the period of seed storage at laboratory $\left(-3\right.$ to $\left.30^{\circ} \mathrm{C}\right)$, refrigeration $\left(5 \pm 1{ }^{\circ} \mathrm{C}\right)$ and freezing $\left(-18 \pm 1{ }^{\circ} \mathrm{C}\right) . \mathrm{M}$ - marker 7,1 to $209 \mathrm{kDa}$; T0 - freshly harvested; T60, T120, and T180 - at 60, 120, and 180 days of storage, respectively; L, R and F - storage at laboratory, refrigeration, and freezer, respectively. 


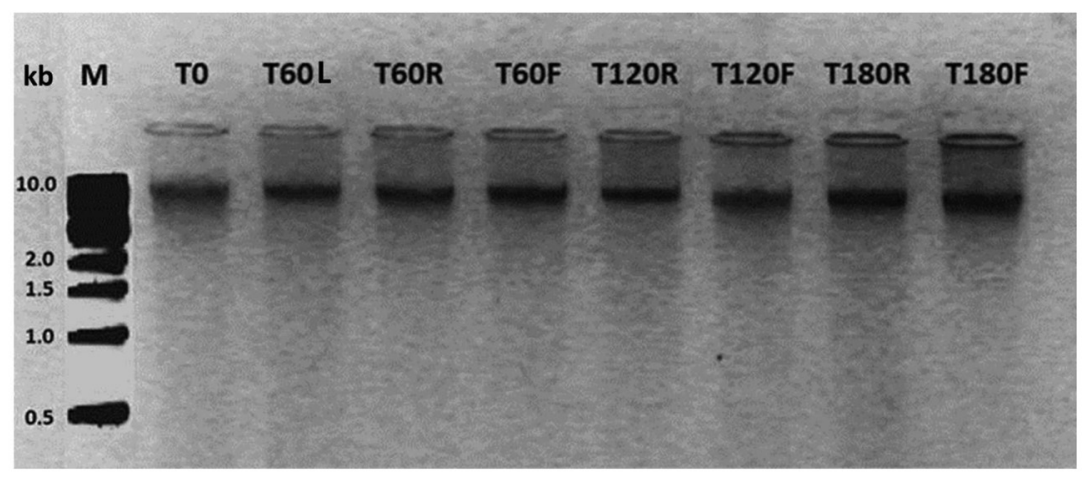

Fig. 4. Agarose gel $(0.8 \%)$ of genomic DNA extracted from Araucaria angustifolia embryos during the period of seed storage at laboratory $\left(-3\right.$ to $\left.30{ }^{\circ} \mathrm{C}\right)$, refrigeration $\left(5 \pm 1{ }^{\circ} \mathrm{C}\right)$, and freezing $\left(-18 \pm 1{ }^{\circ} \mathrm{C}\right) . \mathrm{M}-$ marker 0.5 to $10 \mathrm{~kb}$; T0 - freshly harvested; T60, T120, and T180 - at 60, 120, and 180 days of storage, respectively; L, R and F - storage at laboratory, refrigeration, and freezing, respectively.

and as demonstrated by Garcia et al. (2014). These authors demonstrated that $A$. angustifolia freshly harvested seeds showed $90 \%$ germination and after 180 days of storage, under similar conditions to those here reported, i.e., $\mathrm{L}, \mathrm{R}$, and $\mathrm{F}$, germination decreased to $0 \%$ (L and $\mathrm{F}$ ) and $64 \%(\mathrm{R})$. Besides, moist cold storage with controlled low temperatures has been indicated for the storage of recalcitrant seeds of Araucaria genera (Willan, 1985). These results differ from those observed for orthodox seeds such as Helianthus annuus (sunflower), where storage under $-20{ }^{\circ} \mathrm{C}$ favored the formation of peroxides (José, Salomão, Costa, Silva, \& Curi, 2010). A. angustifolia seeds stored under R, however, showed a small increase in the lipid peroxidation after 180 days of storage. For the rubber tree (Hevea brasiliensis), another species with recalcitrant seeds, an increase in lipid peroxidation was observed during 75 days storage and the reduction in storage temperature $\left(20{ }^{\circ} \mathrm{C} \rightarrow 5^{\circ} \mathrm{C}\right)$ did not change the lipid peroxidation (Paula, Borges, Borges, \& Paula, 1998).

SOD acts by neutralizing the action of superoxide anion $\left(\mathrm{O}_{2}{ }^{--}\right)$through its conversion into hydrogen peroxide $\left(\mathrm{H}_{2} \mathrm{O}_{2}\right)$ and oxygen $\left(\mathrm{O}_{2}\right)$ (Mittler, 2002; Barreiros et al., 2006). The results observed allowed us to infer that there was an increase in the concentration of $\mathrm{O}_{2}{ }^{--}$during embryos storage under $\mathrm{L}$ and $\mathrm{R}$ conditions, that may be related to various damages to cell structures, triggering an increase in SOD activity.

Besides, it is believed that due to the high amplitude of the storage temperature in the laboratory conditions $\left(-3\right.$ to $\left.30{ }^{\circ} \mathrm{C}\right)$, compared to the other treatments in this study, the accelerated metabolic activity may have led to excessive production of $\mathrm{O}_{2}{ }^{--}$, beyond the dismutation capacity of SOD. This may have led to protein degradation, since the antioxidant defense system can be overwhelmed when there is an increase in the concentration of ROS under conditions of high stress (Alscher et al., 2002). Moreover, one can speculate that the respiration activity of the samples may have fallen due to damage of the mitochondrial membranes (Coolbear, 1995) and the unavailability of oxygen and/or low activity of the enzyme NADPH oxidase, may have caused a decrease in the production of $\mathrm{O}_{2}{ }^{--}$(Blokhina et al., 2003).

However, as the activity and integrity of SOD are important in seed storage, the production of $\mathrm{H}_{2} \mathrm{O}_{2}$ by SOD may cause serious cell damage due to the generation of hydroxyl radical $\left(\mathrm{HO}^{\circ}\right)$, considered the most harmful radical to organisms, and cause damage to DNA, RNA, proteins, and cell membranes (Barreiros et al., 2006), besides initiating lipid peroxidation. Thus, the increase in the lipid peroxidation of embryos of seeds stored under $\mathrm{L}$ and $\mathrm{R}$ was triggered by ROS (Wilson \& McDonald, 
1986; Coolbear, 1995). Under the same storage conditions ( $\mathrm{L}$ and $\mathrm{R}$ ), a reduced expression of bands of the electrophoretic profile was observed and therefore increased peroxidation seems to be acting in the degradation of proteins. Similarly, the sharp increase in SOD activity in seeds stored for 120 days in the laboratory coincided with a sharp rise in the level of peroxidation for the same period. The increase in lipid peroxidation during the seeds storage was also observed in embryos of the forest species Melanoxylon brauna, kept for 12 months at $20^{\circ} \mathrm{C}$ and correlated to the increase in SOD activity (Corte et al., 2010). For the species Vigna radiata, the storage at $33{ }^{\circ} \mathrm{C}$ for up to 20 months generated an increase in SOD activity associated with loss of viability and seed deterioration (Murthy, Kumar, \& Sun, 2003).

The low intensity of bands in the electrophoretic pattern of proteins was mainly observed in samples stored under L conditions, demonstrating that the high temperature range during storage might have resulted in protein degradation of embryos. In a similar experiment, the water content was not found to be a limiting factor for the seed viability maintenance, because seed moisture remained above the critical level for the species under such storage conditions (Garcia et al., 2014). It is assumed that similar condition to that of $\mathrm{L}$ would occur if the seeds were kept in their natural environment after dispersal, since they were collected and stored in nearby regions, with similar temperature and air relative humidity (for instance, seeds stored in the city of Lages, $27^{\circ} 49^{\prime} \mathrm{S}-50^{\circ} 19^{\prime} \mathrm{W}$, average altitude of $900 \mathrm{~m}$, Santa Catarina state, Southern Brazil). The protein degradation was also observed in seeds stored under refrigeration, but with lower intensity. Other authors reported that the degradation of proteins in stored seeds of red clover (Trifolium incarnatum) and perennial ryegrass (Lolium perenne) was dependent on the severity of the storage conditions (Ching \& Schoolcraft, 1968). The decrease in the intensity of bands was also observed in seeds of tree species yellow ipe (Handroanthus albus) after storage for 12 months in cold chamber, followed by artificial aging (Shibata, Coelho, Oliveira, \& Garcia, 2012).

Some of the proteins observed may correspond to those described by other authors and identified in mature embryos of $A$. angustifolia. The proteins of $20 \mathrm{kDa}$, whose band showed high intensity, as well as proteins of $15 \mathrm{kDa}$ and $31 \mathrm{kDa}$, may represent the group of vicilins, important proteins in the final stages of zygotic embryogenesis and the most abundant during maturation of the A. angustifolia embryos (Balbuena et al., 2009). It is suggested that these proteins accumulated during embryogenesis and maturation, and are hydrolyzed during the storage of $A$. angustifolia seeds, especially in conditions of ambient temperature. The appearance of the bands $37 \mathrm{kDa}$ and $34 \mathrm{kDa}$ at 180 days of storage under $\mathrm{R}$, which were not present at 60 days and appeared with low intensity at 120 days, may be related to the gradual increase observed in SOD activity. The lack of visible proteins at bands $37 \mathrm{kDa}$ and $34 \mathrm{kDa}$ in samples stored under freezing reinforces the idea that the embryos under the freezing treatment were already dead at 60 days.

As it has been reported by McDonald (1999), the presence of ROS may cause lipid peroxidation, which destroys the nuclear membrane and may lead to DNA degradation. Such event was not observed in A. angustifolia embryos during seed storage. The fact that the DNA bands did not show a conical shape toward the positive pole and that there was not a large amount of DNA retained in the well of the gel indicates the absence of polysaccharides, and if the RNA were present, bands with lower molecular weight would be observed in the gel (Chiari, Valle, \& Resende, 2009). Therefore, the results indicated that there were no methodological flaws, and reinforce the efficacy of the method of DNA extraction with a high degree of purification.

The fact that the DNA samples apparently remained intact during the 180 days of experimental period suggests that the nuclear membrane did not undergo disintegration and acted as protective barriers to DNA. In the case of A. angustifolia, the preparatory metabolism for 
the germination seems to have remained active during the storage because the seeds were kept with high water content. One of the first physiological events at the beginning of seeds germination is the action of repair mechanisms against possible DNA damage, what could affect the synthesis of RNA and proteins (Boubriak, Kargiolaki, Lyne, \& Osborne, 1997). Therefore, it is believed that DNA degradation can occur in the later stages of the deterioration process of $A$. angustifolia seeds, after 180 days of storage.

It was reported that the attack promoted by ROS may cause the destruction of the nuclear membrane and, consequently, DNA degradation (McDonald, 1999). On the other hand, there is the possibility that the DNA remains functional during the decay, and results in the formation of functional mRNA, which can be degraded during storage, impairing the transcription and causing incomplete or defective enzymatic synthesis (McDonald, 1999). Thus, a different experimental design with more detailed level of DNA testing could assess possible functional changes during the germination process.

In summary, the results of the present work revealed an increase in SOD activity in A. angustifolia embryos during seed storage under $\mathrm{L}$ and $\mathrm{R}$ conditions, especially between 60 and 120 days of storage. The former storage condition caused the higher increase in lipid peroxidation compared to the other treatments studied, and also, extensive protein degradation in $A$. angustifolia zygotic embryos. The nuclear DNA of the embryos remained apparently intact after 180 days of storage under $\mathrm{R}$ and $\mathrm{F}$ conditions. Considering the storage conditions, samples under freezing kept the biochemical characteristics throughout the storage period, since the lipid peroxidation and SOD activity remained low, with similar values to freshly harvested seeds, and also no differences were observed in relation to DNA integrity. However, the storage under freezing has originated some bands in the protein profile which are possibly related to the viability loss. Therefore, despite the small changes observed in the samples under R, such a condition can be indicated to delay the metabolic features alterations that occur when seeds are exposed to conditions found in their natural environment after harvest, and thus extending the conservation period of $A$. angustifolia seeds.

\section{ACKNOWLEDGMENTS}

The first author thanks to CAPES for providing a scholarship. The second, the third, the fifth and the last author thank to CNPq for the research productivity fellowships granted.

\section{RESUMEN}

Cambios bioquímicos en embriones cigóticos de Araucaria angustifolia (Araucariaceae) durante el almacenamiento. Especies reactivas del oxígeno (ROS) están presentes en todos los organismos aeróbicos, pero los procesos de deterioro de semillas pueden aumentar su producción. El estrés oxidativo causado por el aumento de ROS endógeno puede causar un daño irreparable a las células, que conduce a la pérdida de viabilidad de la semilla. Teniendo en cuenta que la enzima superóxido dismutasa (SOD) compone el primer mecanismo de defensa antioxidante enzimática, este estudio tuvo por objetivo evaluar los embriones cigóticos de semillas recalcitrantes de Araucaria angustifolia durante el almacenamiento los cambios en la actividad de SOD. Además, algunas alteraciones importantes derivadas de estrés oxidativo, como la peroxidación lipídica y los cambios en las proteínas y la integridad del DNA también se evaluaron. Aproximadamente 7000 semillas fueron cosechadas de una población en el sur de Brasil y almacenadas durante 180 días en el laboratorio $(\mathrm{L})$, refrigeración $(\mathrm{R})$ y congelamiento $(\mathrm{F})$. El análisis de la peroxidación de lípidos a través de los niveles de TBARS, actividad de la SOD, perfil proteico por separación electroforética e integridad del DNA genómico se realizaron a los 0, 60, 120 y 180 días de almacenamiento. Los resultados revelaron un aumento de la peroxidación lipídica y de la actividad de la SOD, especialmente durante el almacenamiento en $\mathrm{L}$, una condición en la que hubo una extensa degradación de las proteínas. Algunas proteínas (45, 32 y $31 \mathrm{kDa}$ ) se expresaron sólo en embriones almacenados en condiciones R y F. No se observaron daños en la integridad del DNA nuclear para el período de almacenamiento de semillas en condiciones R y F. Las muestras F mantienen las características bioquímicas analizadas durante todo el período de almacenamiento, con la excepción del perfil de proteínas. Sin embargo, tales cambios son limitantes para el mantenimiento de la viabilidad de la semilla. En conclusión, el almacenamiento en refrigeración puede ser indicado para retrasar las alteraciones metabólicas que 
se producen cuando las semillas están expuestas a condiciones de ambiente natural después de la cosecha, que extiende el período de conservación de las semillas de $A$. angustifolia.

Palabras clave: Piño Brasileño, semillas recalcitrantes, deterioro de las semillas, estrés oxidativo, superóxido dismutasa.

\section{REFERENCES}

Alfenas, A. C. (1998). Eletroforese de isoenzimas e proteinas afins: fundamentos e aplicações em plantas e microrganismos. Viçosa, MG: UFV.

Alscher, R. G, Erturk, N., \& Health, L. S. (2002). Role of superoxide dismutases (SODs) in controlling oxidative stress in plants. Journal of Experimental Botany, $53,1331-1341$.

Amarante, C. V. T., Mota, C. S., Megguer, C. A., \& Ide, G. M. (2007). Conservação pós-colheita de pinhões [sementes de Araucaria angustifolia (Bertoloni) Otto Kuntze] armazenados em diferentes temperaturas. Ciência Rural, 37, 346-351.

Auler, N. M. F., Reis, M. S., Guerra, M. P., \& Nodari, R. O. (2002). The genetics and conservation of Araucaria angustifolia: I. Genetic structure and diversity of natural populations by means of non-adaptive variation in the state of Santa Catarina, Brazil. Genetics and Molecular Biology, 25, 329-338.

Balbuena, T. S., Silveira, V., Junqueira, M., Dias, L. L. C., Santa-Catarina, C., Shevchenko, A., \& Floh, E. I. S. (2009). Changes in the 2-DE protein profile during zygotic embryogenesis in the Brazilian Pine (Araucaria angustifolia). Journal of Proteomics, 72, 337-352.

Balbuena, T. S., Jo, L., Pieruzzi, F. P., Dias, L. L. C., Silveira, V., Santa-Catarina, C., ..., \& Floh, E. I. S. (2011). Differential proteome analysis of mature and germinated embryos of Araucaria angustifolia. Phytochemistry, 72, 302-311.

Barbedo, C. J., \& Marcos Filho, J. (1998). Tolerância à dessecação de sementes. Acta Botânica Brasilica, $12,145-164$.

Barreiros, A. L. B. S., David, J. M., \& David, J. P. (2006). Estresse oxidativo: relação entre geração de espécies reativas e defesa do organismo. Química Nova, 29, 113-123.

Bewley, J. D., \& Black, M. (1994). Seeds: physiology of development and germination. New York, NY: Plenum Press.

Blokhina, O., Virolainen, E., \& Fagerstedt, K. V. (2003). Antioxidants, oxidative damage and oxygen deprivation stress: a review. Annals of Botany, 91, 179-194.
Boubriak, I., Kargiolaki, H., Lyne, L., \& Osborne, D. J. (1997). The requirement for DNA repair in desiccation tolerance of germinating embryos. Seed Science Research, 7, 97-105.

Bradford, M. M. (1976). A rapid and sensitive method for the quantitation of microgram quantities of protein utilizing the principle of protein-dye binding. Analytical Biochemistry, 72, 248-254.

Chiari, L., Valle, J. V. R., \& Resende, R. M. S. (2009). Comparação de três métodos de extração de DNA genômico para análises moleculares em Stylosanthes guianensis. Campo Grande, MS: Embrapa-CNPGC.

Ching, T. M., \& Schoolcraft, I. (1968). Physiological and chemical differences in aged seeds. Crop Science, 8 , 407-409.

Coolbear, P. (1995). Mechanisms of seed deterioration. In A. S. Basra (Ed.), Seed quality: basic mechanisms and agricultural implications (pp. 223-277). New York, NY: Food Products Press.

Corbineau, F. (2012). Markers of seed quality: from present to future. Seed Science Research, 22, S61-S68.

Corte, V. B., Borges, E. E. L., Leite, H. G., Pereira, B. L. C., \& Gonçalves, J. F. C. (2010). Estudo enzimático da deterioração de sementes de Melanoxylon brauna submetidas ao envelhecimento natural e acelerado. Revista Brasileira de Sementes, 32, 83-91.

Doyle, J. J., \& Doyle, J. L. (1987). A rapid DNA isolation procedure for small quantities of fresh leaf tissue. Phytochemical Bulletin, 19, 11-15.

Doyle, J. J., \& Doyle, J. L. (1990). Isolation of plant DNA from fresh tissue. Focus, 12, 13-15.

Epagri/Ciram. (2011). Atlas climatológico do estado de Santa Catarina. Retrieved from http://www.ciram. epagri.rct-sc.br

Farias-Soares, F. L., Burrieza, H. P., Steiner, N., \& Guerra, M. P. (2013). Immunoanalysis of dehydrins in Araucaria angustifolia embryos. Protoplasma, 250, 911-918.

Ferrandis, P., Bonilla, M., \& Osorio, L. C. (2011). Germination and soil seed bank traits of Podocarpus angustifolius (Podocarpaceae): an endemic tree species from Cuban rain forests. Revista de Biología Tropical, 59(3), 1061-1069.

Fowler, J. A. P., Bianchetti, A., \& Zanon, A. (1998). Conservação de sementes de pinheiro-do-paraná sob diferentes condições de ambientes e embalagens. Embrapa: Comunicado Técnico, 34, 1-4.

Garcia, C., Coelho, C. M. M., Maraschin, M., \& Oliveira, L. M. (2014). Conservação da viabilidade e vigor de sementes de Araucaria angustifolia (Bert.) O. Kuntze durante o armazenamento. Ciência Florestal, 24(4), 857-866. 
Gill, S. S., \& Tuteja, N. (2010). Reactive oxygen species and antioxidant machinery in abiotic stress tolerance in crop plants. Plant Physiology and Biochemistry, 48, 909-930.

Halliwell, B., \& Gutteridge, J. M. C. (1999). Free Radicals in Biology and Medicine. New York, NY: Oxford University Press.

José, S. C. B. R, Salomão, A. N., Costa, T. S. A., Silva, J. T. T. T., \& Curi, C. C. S. (2010). Armazenamento de sementes de girassol em temperaturas subzero: aspectos fisiológicos e bioquímicos. Revista Brasileira de Sementes, 32, 29-38.

Laemmli, U. K. (1970). Cleavage of structural proteins during the assembly of the head of bacteriophage T4. Nature, 227, 680-685.

Li, D. Z., \& Pritchard, H. W. (2009). The science and economics of ex situ plant conservation. Trends in Plant Science, 14, 614-621.

Löwe, T. R., \& Dillenburg, L. R. (2011). Changes in light and nutrient availabilities do not alter the duration of use of seed reserves in Araucaria angustifolia seedlings. Australian Journal of Botany, 59, 32-37.

McDonald, M. B. (1999). Seed deterioration: phisiology, repair and assessment. Seed Science and Technology, 27, 177-237.

Misra, H. P., \& Fridovich, I. (1972). The role of superoxide anion in the autoxidation of epinephrine and a simple assay for superoxide dismutase. Journal of Biology and Chemistry, 247, 188-192.

Mittler, R. (2002). Oxidative stress, antioxidants and stress tolerance. Trends Plant Science, 7, 405-410.

Murthy, U. M. N., Kumar, P. P., \& Sun, W. Q. (2003). Mechanisms of seed ageing under different storage conditions for Vigna radiata (L.) Wilczek: lipid peroxidation, sugar hydrolysis, Maillard reactions and their relationship to glass state transition. Journal of Experimental Botany, 54, 1057-1067.

Nakada, P. G., Oliveira, J. A., Melo, L. C., Silva, A. A., Silva, P. A., \& Perina, F. J. (2010). Desempenho durante o armazenamento de sementes de pepino submetidas a diferentes métodos de secagem. Revista Brasileira de Sementes, 32, 42-51.

Ohkawa, H., Ohishi, H., \& Yagi, K. (1979). Assay for lipid peroxyde in animal tissues by thiobarbituric acid reaction. Analytical Biochemistry, 95, 351-358.

Pammenter, N. W., \& Berjak, P. (2000). Aspects of recalcitrant seed physiology. Revista Brasileira de Fisiologia Vegetal, 12, 56-69.
Paula, N. F., Borges, E. E. L., Borges, R. C. G., \& Paula, R. C. (1997). Alterações físiológicas em sementes de seringueira (Hevea brasiliensis Muell. Arg.) durante o armazenamento. Revista Brasileira de Sementes, 19, 327-334.

Paula, N. F., Borges, E. E. L., Borges, R. C. G., \& Paula, R. C. (1998). Avaliações bioquímicas e fisiológicas em sementes de seringueira (Hevea brasiliensis Muell. Arg.). Revista Brasileira de Sementes, 20, 1-10.

Rendón, M. Y., Gratão, P., Salva, T. J. G., Azevedo, R. A., \& Bragagnolo, N. (2013). Antioxidant enzyme activity and hydrogen peroxide content during the drying of Arabica coffee beans. European Food Research and Technology, 236, 753-758.

Rosenfield, M. F., \& Souza, A. F. (2014). Forest biomass variation in Southernmost Brazil: the impact of Araucaria trees. Revista de Biología Tropical, 62(1), 359-372.

Santos, C. M. R., Menezes, N. L., \& Villela, F. A. (2004). Alterações fisiológicas e bioquímicas em sementes de feijão envelhecidas artificialmente. Revista Brasileira de Sementes, 26, 110-119.

SAS. (2009). SAS - Statistical Analysis System (Version 9.2). Cary, NC, Lic. UDESC: SAS Institute Inc.

Shibata, M., Coelho, C. M. M., Oliveira, L. M., \& Garcia, C. (2012). Accelerated aging of ipê seeds under controlled conditiond of storage. Revista Brasileira de Sementes, 34, 247-254.

Smith, M. T., \& Berjak, P. (1995). Deteriorative changes associated with loss of viability of stored dessication-tolerant and dessication-sensitive seeds. In J. Kiegel, \& G. Galili (Eds.), Seed development and germination (pp. 701-746). New York, NY: Marcel Dekker Inc.

Song, S. Q., Berjak, P., Pammenter, N., Ntuli, T. M., \& Fu, J. R. (2003). Seed recalcitrance: a current assessment. Acta Botania Sinica, 45, 638-643.

Steiner, N. (2005). Parâmetros fisiológicos e bioquímicos durante e embriogênese zigótica e somática de Araucaria angustifolia (Bert.) O. Kuntze (Master's degree), Federal University of Santa Catarina, Florianópolis.

Thomas, P. (2013). Araucaria angustifolia. In IUCN Red List of Threatened Species. Version 2013.2. Retrieved from http://www.iucnredlist.org

Veloso, H. P., Rangel Filho, A. L. R., \& Lima, J. C. A. (1991). Classificação da vegetação brasileira, adaptada a um sistema universal. Rio de Janeiro, RJ: IBGE - Fundação Instituto Brasileiro de Geografia e Estatística. 
Vibrans, A. C., Sevegnani, L., Uhlmann, A., Schorn, L. A., Sobral, M. G., Gasper, A. L., ..., \& Verdi, M. (2011). Structure of mixed ombrophyllous forests with Araucaria angustifolia (Araucariaceae) under external stress in Southern Brazil. Revista de Biologia Tropical, 59(3), 1371-1387.

Vidas, R. M. R., Moreira, M. A., Pinheiro, W. J., Rocha, V. S., Rezende, S. T., \& Sediyama, C. S. (1992). Relação entre vigor e alterações bioquímicas na germinação de sementes de soja. Revista Brasileira de Fisiologia, 4, 49-53.
Villela, F. A., \& Peres, W. B. (2004). Coleta, beneficiamento e armazenamento. In A. G. Ferreira \& F. Borghetti (Eds.), Germinação: do básico ao aplicado (pp. 265281). Porto Alegre, RS: Artmed.

Willan R. L. (1985). A guide to forest seed handling: with special reference to the tropics. Roma: Food and agriculture organization of the United Nations.

Wilson, D. O., \& McDonald, M. B. (1986). The lipid peroxidation model of seed aging. Seed Science and Technology, 14, 296-300. 